\title{
Health asset profiles and health indicators among 13- and 15-year-old adolescents
}

\author{
Leena Paakkari ${ }^{1} \cdot$ Minna Torppa $^{2} \cdot$ Raili Välimaa $^{1} \cdot$ Jari Villberg $^{1} \cdot$ Kristiina Ojala $^{1} \cdot$ Jorma Tynjälä $^{1}$
}

Received: 31 October 2018/Revised: 17 April 2019/Accepted: 27 June 2019/Published online: 12 July 2019

(C) The Author(s) 2019

\begin{abstract}
Objectives We examined the associations between adolescents' health assets and various health indicators (smoking, alcohol use, sleep length, physical activity, healthy eating, oral health, self-reported health, multiple health complaints). Methods A nationally representative sample was drawn from Finnish-speaking schools, comprising 13- and 15-year-old adolescents $(n=3833)$. The measures taken covered the adolescents' health assets, which were labelled Family-financial, Psychological, Family-social, Friends-social, School-social, and Human. Our analysis applied two-step cluster analysis and multilevel mixed-effects binary logistic regression.

Results Six asset profiles were identified: 'Limited in most assets, despite medium affluence', 'Mostly average assets, but low affluence', 'Mostly average assets, though high affluence', 'Mostly above average assets', 'Rich in most assets', and 'Rich in all assets'. There were significant differences between the profiles in terms of risk level and desirable level health outcomes.

Conclusions Adolescents differ in their asset profiles. Having multiple health assets appears to protect adolescents from risky behaviour or poor health, and to promote positive health. There is a need for health initiatives to develop a range of health-protecting and health-promoting assets, rather than focus on only one.
\end{abstract}

Keywords Adolescents $\cdot$ Health assets $\cdot$ Profiles $\cdot$ Health indicator

\section{Introduction}

During the last decade, an ever-greater emphasis has been placed on how the circumstances in which people live, grow, develop, and work (i.e. the social determinants of health; Marmot 2005; World Health Organization 2008) contribute to health disparities. Among adolescents, the social determinants of health have been of particular interest, since (as noted by Viner et al. 2012, p. 1643) the

Electronic supplementary material The online version of this article (https://doi.org/10.1007/s00038-019-01280-7) contains supplementary material, which is available to authorized users.

Leena Paakkari

leena.paakkari@jyu.fi

1 Research Center for Health Promotion, Faculty of Sport and Health Sciences, University of Jyväskylä, P.O. Box 35 (L), 40014 Jyväskylä, Finland

2 Department of Teacher Education, University of Jyväskylä, Jyväskylä, Finland effects of these determinants are crucially important for the health of entire populations and for national economic development. With these considerations in mind, in efforts to enhance adolescents' health, more emphasis has been placed on promoting various health-protecting factors than on merely reducing health risks (Viner et al. 2012). Furthermore, achieving good health would seem to require a comprehensive approach in which externally situated factors would be combined with individual-level factors (Forde and Raine 2008). The aim of understanding healthproducing elements at various levels is given special emphasis within health assets research (Brooks and Kendall 2013).

In the field of public health and health promotion, the concept of 'health assets' has attracted considerable interest in the 21 st century. A health asset can be defined as 'any factor (or resource), which enhances the ability of individuals, groups, communities, populations, social systems and/or institutions to maintain and sustain health and well-being, and to help reduce inequalities' (Morgan and Ziglio 2007, p. 18). Assets can be both external and 
internal (Brooks and Kendall 2013; see also Leffert et al. 1998), thus being situated within individuals (e.g. self-esteem, skills) but also within institutions or communities (involving, e.g. family-social support, school connectedness). In fact, from their roots in theories such as salutogenesis, resilience, and social capital (Brooks and Kendall 2013), the central elements of assets-based thinking go back to the 1970s or even earlier. Moreover, similarities can be found with the concept of a 'developmental asset', which was introduced in the 1990s as part of a focus on young people's assets as 'positive factors that contribute to healthy development' (Benson et al. 1999, p. 5). This approach has its background in research related to resilience, but also to prevention (Benson et al. 1999). In general, an asset-based approach encompasses the notion that instead of focusing on health risks and on the prevention of diseases, more emphasis should be put on the factors that constitute health and well-being (Benson et al. 1999; Morgan and Ziglio 2007). Deriving from such considerations, the aim has been to find a balance between assets approaches and risk-focused (deficit) approaches (Benson et al. 1999; Morgan and Ziglio 2007), meaning that the factors that society positively desires for its young people should be brought into the agenda, rather than merely the negative indicators that should be avoided (Murphey et al. 2004).

The recommendation to focus on health-producing factors is not new, and there has in fact been considerable research on asset-related factors, including various sorts of capital and their contribution to health (e.g. health-relevant cultural capital, Abel 2008; cultural health capital, Shim 2010). To give a few examples, meta-analyses have indicated a modest but significant association between social capital and health (Gilbert et al. 2013) and well-being (Chu et al. 2010). Chu et al. (2010) found that among adolescents the social support gained from teachers and other school personnel had a stronger association with well-being than that gained from family, friends, or other sources, and further, that perceived support was more important than enacted support. Interestingly, the size of one's networks has only a minimal relationship with well-being (Chu et al. 2010). Asset research has confirmed the important role of both home and out-of-home settings (e.g. school, neighbourhood) in supporting positive health outcomes, and in protecting from risky behaviours (e.g. Brooks et al. 2012; Fulkerson et al. 2006; García-Moya et al. 2015; Klemera et al. 2017). In addition, family-financial or economic capital has been clearly linked to adolescents' health. Family affluence explains childhood health disparities (Inchley et al. 2016), and the low socio-economic status of families is associated with poorer health outcomes among adolescents (e.g. Reiss 2013). Overall, as argued by Viner et al. (2012, p. 1647), it seems to be the case that "proximal determinants related to social and educational domains [e.g. school, family, peers, and neighbourhood] affect the differences in exposure and vulnerability of young people to health-compromising conditions'.

Research examining the associations between assets and health indicators has mainly focused on a few selected assets. However, few studies have included many assets, to examine whether having more assets makes a larger contribution to adolescents' health than having fewer assets. One such study is that of Murphey et al. (2004), who found that the number of assets (e.g. academic achievement, connectedness to parents, and feeling valued by the community) was related to engagement in various health behaviours. Having fewer assets was associated with a greater likelihood of engaging in risky behaviours; conversely, having more assets was associated with healthenhancing behaviour. In summarizing the matter, Benson et al. (2011) conclude that assets appear to be additive in nature, and that there may be certain sets of assets that predict certain health outcomes. However, so far not much is known about the range of asset profiles that may exist among adolescents, and how these may be related to various health outcomes. Identification of these asset profiles goes beyond mere consideration of the average experiences of adolescents, allowing exploration of "the interindividual variability and complexity that is a hallmark of human growth' (Benson et al. 2011, p. 218).

In this paper, we use 'health asset' as a general term to describe the resources of an individual that may promote or maintain health. Such resources can be expected to be both internal (designated as Human, Psychological) and external (designated as School-social, Friends-social, Family-social, Family-financial). This paper thus aims (1) to identify the health asset profiles of 13- and 15-year-old adolescents and (2) to examine the association of the health asset profiles with various health indicators (smoking, alcohol use, length of sleep, physical activity, healthy eating, oral health, self-reported health, multiple health complaints).

\section{Methods}

\section{Participants}

A nationally representative sample from Finnish-speaking schools was collected in Finland during March-May 2014, as part of the Health Behaviour in School-aged Children (HBSC) study. In total, 3833 adolescents from 359 schools took part in the survey. The schools were chosen from the Finnish school register using a cluster sampling method. Sampling was adjusted to take into account the province within Finland, the type of municipality (urban, semi-urban, rural), and the size of the school (PPS, Proportion 
Probable Size). The participating classes were selected randomly within each school. Pupils aged 13 and 15 responded during one lesson (45 $\mathrm{min})$ to a standardized paper-and-pen questionnaire. The participants were aware of the confidentiality of the data, and they responded voluntarily and anonymously. The response rate for schools was $68 \%$, while the response rate for the pupils within the participating schools was $85 \%$.

\section{Measures}

\section{Health assets}

Health assets were divided into six categories designated as Family-financial, Psychological, Family-social, Friendssocial, School-social, and Human (Table 1). The Familyfinancial asset was measured via the Family Affluence
Scale (FAS III; Torsheim et al. 2016). The Psychological asset was measured by a self-esteem scale (Rosenberg 1965) plus the Body Investment Scale (BIS, subscale on body image; Orbach and Mikulincer 1998). The Familysocial asset was measured by eight scales measuring family routines (eating together, family eating rules, supporting physical activity), general and school-related social support, family communication, quality of family communication, and parental monitoring (Brown et al. 1993). The Friends-social asset was measured by communication, general support (Zimet et al. 1988), student support, and loneliness. The School-social asset was measured by four scales, covering teacher support, school-related competence/autonomy, participation, and school perceptions. The Human asset was measured by learning difficulties in reading and mathematics, educational aspiration (upper secondary school or vocational school), and health literacy

Table 1 Health assets: designations, scales, and measures obtained

\begin{tabular}{|c|c|c|c|}
\hline & Range & Mean & $\mathrm{SD}$ \\
\hline Family-financial & Low $0-6$ & 8.5 & 1.84 \\
\hline One scale, six items, e.g. 'How many computers (PCs, Macs, or laptops) does your family own?' & $\begin{array}{l}\text { Medium } \\
7-9 \\
\text { High } \\
\quad 10-13\end{array}$ & & \\
\hline Psychological & $27-120$ & 86.2 & 14.0 \\
\hline
\end{tabular}

Two scales:

Self-esteem scale, 10 items, e.g. 'On the whole I am satisfied with myself'.

Emotional investment of the body, six items, e.g. 'I am satisfied with my appearance'

Family-social

$45-153 \quad 112.3 \quad 17.0$

Eight scales (35 items):

Including Parental monitoring, six items, e.g. 'How much your mother/father really know about what you do with your free time?'

Friends-social

Four scales:

Communication (one item), Loneliness (one item), General and school-related social support (four items), e.g. 'I can talk about my problems with my friends'

School-social

Four scales:

Teacher support (three items), School-related competence/autonomy (eight items), Participation (three items), School perceptions (five items), e.g. 'Our school is a nice place to be'

\section{Human}

Three scales (19 items):

$\begin{array}{lll}1-51 & 42.3 & 6.0 \\ 10-40 & 32.7 & 5.4\end{array}$

Learning difficulties in reading and spelling, and mathematics

Educational aspiration: via question: 'What do you think you will do when you finish comprehensive school?' Options: 'Try to enter to 'upper secondary school', 'double examination' (i.e. for upper secondary school and vocational school), 'vocational school or other vocational training', 'an apprenticeship', 'get a job', 'be unemployed' 'don't know'.

Health literacy: via Health Literacy among School-Aged Children (HLSAC) instrument: 10 items, starting with 'I am confident that...', and continuing with items such as 'When necessary I find health-related information that is easy for me to understand'

Health Behaviour in School-aged Children (HBSC) study, Finland, 2014 
(HLSAC; Paakkari et al. 2016). (Supplementary Table 1 'Health assets variables').

\section{Health indicators}

The health indicators were chosen to give a broad picture of health and to comprise a range of health-enhancing (healthy food, oral health, physical activity, sleep length) and health impairing (alcohol use, smoking) behaviours, and perceived health indicators (health complaints, selfrated health) (Table 2). The healthy food index indicated the frequency of eating vegetables and fruits. Oral health was measured by the frequency of toothbrushing. Physical activity, defined as 'any activity that increases your heart rate and makes you get out of breath some of the time', was evaluated with the moderate-to-vigorous physical activity (MVPA) scale (Prochaska et al. 2001). In addition, sleep length on school nights and smoking was estimated. Alcohol use was measured by times being drunk.

Perceived health was rated by multiple self-rated health complaints over the last six months, using the HBSC-SCL symptom checklist (Ravens-Sieberer et al. 2008) and by selfrated health $(\mathrm{SRH})$, which was measured by a single item (Haugland et al. 2001). Health indicators were divided into 'risk level' and 'desirable level' based on the risk levels used in the international report on HBSC results (Inchley et al. 2016) and on for example national recommendations (e.g. recommendation on physical activity for health).

\section{Statistical analysis}

Two-step cluster analysis was used to identify asset profiles, using categorical and continuous variables. This classification method builds profiles based on similarities in assets. It aims to maximize between-profile variance while minimizing within-profile variance (see Ketchen and Shook 1996). In identifying the cluster solution, we allowed the analysis method to automatically determine the number of the clusters (using Schwarz's Bayesian Information Criterion) and also tested various fixed numbers of clusters. In deciding on the final cluster solution, the following issues were taken into account: cluster quality

Table 2 Measures used on health indicators (health behaviour and perceived health indicators) $(n=3007-3852)$

\begin{tabular}{|c|c|c|c|c|c|c|c|}
\hline & $\begin{array}{l}\text { Item categories/ } \\
\text { score }\end{array}$ & Risk level & Desirable level & $\begin{array}{l}\text { Min/ } \\
\text { Max } \\
\text { score }\end{array}$ & Mean & $\mathrm{SD}$ & $\begin{array}{l}\text { Crh } \\
\alpha\end{array}$ \\
\hline $\begin{array}{l}\text { Oral health } \\
\text { How often do you brush your teeth? }\end{array}$ & $\begin{array}{l}1=\text { more than } \\
\text { once a day to } \\
5=\text { never }\end{array}$ & $<2$ times/day & $>1$ times/day & $1 / 5$ & 1.49 & 0.69 & - \\
\hline $\begin{array}{l}\text { Healthy food } \\
\text { Two items: Frequency of eating fruits/vegetables } \\
\text { How many times do you usually eat...? }\end{array}$ & $\begin{array}{l}1 \text { = never to } \\
7 \text { = every day, } \\
\text { more than once }\end{array}$ & $\begin{array}{l}\text { 0-4 times/ } \\
\text { week }\end{array}$ & $\geq 7$ times/week & $0 / 14$ & 8.90 & 2.58 & 0.74 \\
\hline $\begin{array}{l}\text { Alcohol use } \\
\text { During your lifetime, have you ever had so much } \\
\text { alcohol that you were really drunk? }\end{array}$ & $\begin{array}{l}\text { Never to more } \\
\text { than } 10 \text { times }\end{array}$ & $\geq 2$ times & Never & & & & \\
\hline $\begin{array}{l}\text { Physical activity } \\
\text { Over the past } 7 \text { days, on how many days were you } \\
\text { physically active for a total of at least } 60 \text { min per } \\
\text { day? }\end{array}$ & 0 to 7 days & 0-2 days/week & 7 days/week & $0 / 7$ & 4.50 & 1.92 & - \\
\hline $\begin{array}{l}\text { Smoking } \\
\text { How often do you smoke tobacco at present? }\end{array}$ & $\begin{array}{l}1 \text { = every day to } \\
4 \text { = I don't } \\
\text { smoke }\end{array}$ & $\begin{array}{l}\text { Weekly or } \\
\text { more often }\end{array}$ & Do not smoke & $1 / 4$ & 3.72 & 0.77 & - \\
\hline $\begin{array}{l}\text { Sleep length } \\
\text { Difference between bedtime and wake-up time }\end{array}$ & Hours & $\leq 7 \mathrm{~h}$ & $\geq 8.5 \mathrm{~h}$ & $3 / 11$ & 8.09 & 0.99 & - \\
\hline $\begin{array}{l}\text { Self-rated health } \\
\text { Would you say your health is.....? }\end{array}$ & $\begin{array}{l}1=\text { excellent to } \\
4=\text { poor }\end{array}$ & Fair or poor & Excellent or good & $1 / 4$ & 1.95 & 0.67 & - \\
\hline $\begin{array}{l}\text { Multiple health complaints } \\
\text { In the last } 6 \text { months: how often have you had the } \\
\text { following....? headache, stomach-ache, backache, } \\
\text { feeling low, irritability or bad temper, feeling } \\
\text { nervous, difficulties in getting to sleep, feeling dizzy }\end{array}$ & $\begin{array}{l}1=\text { almost daily } \\
\text { to } 5=\text { more } \\
\text { seldom or never }\end{array}$ & $\begin{array}{l}\geq 2 \text { symptoms } \\
\text { more than } \\
\text { once a week }\end{array}$ & $\begin{array}{l}\leq 2 \text { symptoms } \\
\text { once a month or } \\
\text { seldom/never }\end{array}$ & $0 / 8$ & 2.81 & 2.33 & 0.85 \\
\hline
\end{tabular}

The Health Behaviour in School-aged Children (HBSC) study, Finland, 2014 
('fair' or better $>0.2$ ), the predictor importance of assets in estimating the cluster model, the size of the clusters, and the interpretability. A one-way analysis of variance with Dunnett's T3 pairwise test (SPSS 24) was utilized to compare the clusters. Multilevel mixed-effects binary logistic regression analyses were applied, using Stata (version 15) to test whether the clusters differed from each other in health behaviours and health indicators, and whether the results varied by school. The results are presented with the age group and gender adjusted.

\section{Results}

\section{Identification of the health asset profiles}

Having critically examined models from two to seven clusters, we ended up with a six-cluster model. The cluster solution had an average silhouette of 0.3 , which suggests a fair fit with the data. As predictors of the cluster model (i.e. having a predictor importance value ranging from 0 to 1 ; IBM 2012), the assets were ranked thus: Family-social (1.0) and Family- financial (1.0), followed by Psychological (0.92), Friends-social (0.72), School-social (0.71) and Human (0.48). Figure 1 and Table 3 present the means and standard deviations for the assets in each cluster, and the statistical differences between the mean values of the clusters.

The largest cluster ( $28.8 \%$ of the sample, $n=1061)$ was referred to as 'Limited in most assets, despite medium affluence'. This was constituted from pupils who had medium family affluence, but who otherwise had fewer health assets than pupils in the other clusters (Table 3). The clusters 'Mostly average assets, but low affluence' (13.2\%, $n=488$ ) and 'Mostly average assets, though high affluence' $(21.4 \%, n=790)$ moved in a roughly parallel direction, but showed statistically significant differences in terms of Family-financial and School-social assets. The cluster designated 'Mostly above average assets' (18.2\%, $n=673$ ) included pupils whose assets (other than Familyfinancial) were on average higher than those in clusters $1-3$. The clusters 'Rich in most assets' $(11.5 \%, n=426)$ and 'Rich in all assets' $(6.8 \%, n=252)$ included pupils with the highest asset measures overall. Except for differences in Family-financial and Psychological assets, there were no statistically significant differences between these two clusters (Table 3 ).

\section{Comparing health indicators between clusters}

The proportions of adolescents who were categorized as being in a risk group, in terms of the various health indicators included in this study, varied from $4.3 \%$ (healthy food) to $40.2 \%$ (oral health). The proportions of adolescents who reached the desirable level varied from $21.3 \%$ (physical activity) to $86.3 \%$ (smoking). Table 4 reports, for each asset cluster, the percentage of pupils falling into the risk group, and those reaching the desirable level.

In the multilevel logistic regression analyses to determine whether the asset clusters were linked to health indicators (risky or desirable) the 'Limited in most assets, despite medium affluence' cluster was used as a reference
Fig. 1 Asset profiles with standardized scores $(\mathrm{M}=0$, $\mathrm{SD}=1$ ), except for Familyfinancial, where the raw scores $1,2,3$ were changed to $-1,0$, 1). Health Behaviour in Schoolaged Children (HBSC) study, Finland, 2014

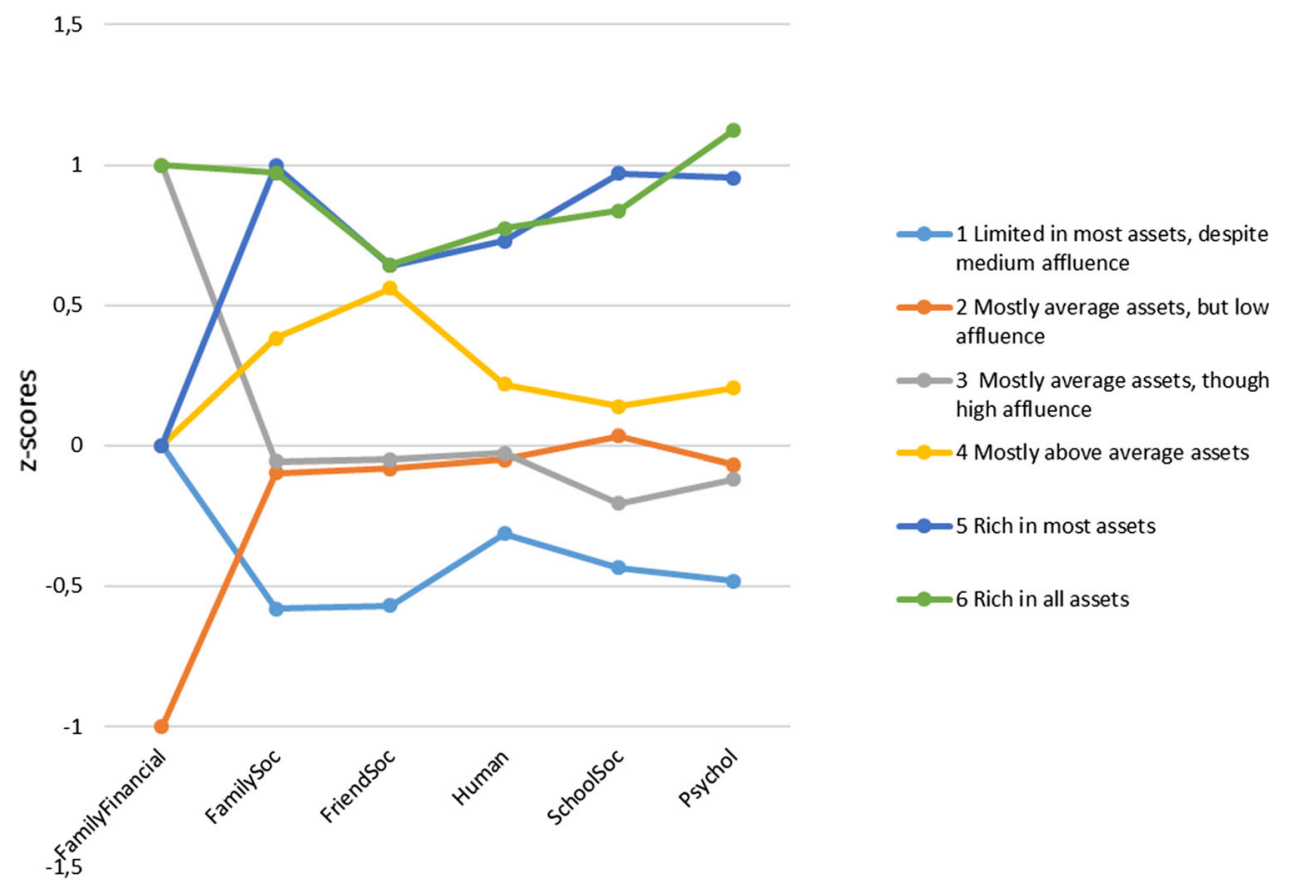


Table 3 Descriptive statistics and cluster comparisons for the asset measures

\begin{tabular}{|c|c|c|c|c|c|c|c|c|c|c|c|c|c|c|}
\hline & \multicolumn{2}{|c|}{$\begin{array}{l}1 \text { Limited in } \\
\text { most assets, } \\
\text { despite } \\
\text { medium } \\
\text { affluence }\end{array}$} & \multicolumn{2}{|c|}{$\begin{array}{l}2 \text { Mostly } \\
\text { average } \\
\text { assets, but } \\
\text { low affluence }\end{array}$} & \multicolumn{2}{|c|}{$\begin{array}{l}3 \text { Mostly } \\
\text { average } \\
\text { assets, though } \\
\text { high } \\
\text { affluence }\end{array}$} & \multicolumn{2}{|c|}{$\begin{array}{l}4 \text { Mostly } \\
\text { above } \\
\text { average } \\
\text { assets }\end{array}$} & \multicolumn{2}{|c|}{$\begin{array}{l}5 \text { Rich in } \\
\text { most } \\
\text { assets }\end{array}$} & \multicolumn{2}{|c|}{$\begin{array}{l}6 \text { Rich in } \\
\text { all assets }\end{array}$} & \multirow[t]{2}{*}{$\mathrm{F}(5,3645)$} & \multirow[t]{2}{*}{ Pairwise (Dunnett-T3) } \\
\hline & M & SD & M & SD & M & SD & M & SD & M & SD & M & SD & & \\
\hline Family-social & -0.58 & 0.81 & -0.10 & 0.91 & -0.05 & 0.83 & 0.38 & 0.50 & 1.00 & 0.45 & 0.97 & 0.43 & $416.26 * * *$ & $\begin{array}{c}2=3,5=6, \text { others } \\
\text { differ }^{1}\end{array}$ \\
\hline $\begin{array}{c}\text { Friends- } \\
\text { social }\end{array}$ & -0.57 & 0.99 & -0.08 & 1.01 & -0.05 & 0.97 & 0.56 & 0.39 & 0.64 & 0.49 & 0.64 & 0.50 & $239.29 * * *$ & $\begin{array}{c}2=3,4=5=6, \text { others } \\
\text { differ }\end{array}$ \\
\hline Human & -0.31 & 0.99 & -0.05 & 0.91 & -0.03 & 0.92 & 0.22 & 0.56 & 0.73 & 0.34 & 0.78 & 0.30 & $150.55 * * *$ & $\begin{array}{l}2=3,5=6, \text { others } \\
\text { differ }\end{array}$ \\
\hline School-social & -0.43 & 0.91 & 0.03 & 0.94 & -0.20 & 0.92 & 0.14 & 0.61 & 0.97 & 0.67 & 0.84 & 0.75 & $233.17 * * *$ & $\begin{array}{l}2=4,5=6, \text { others } \\
\text { differ }\end{array}$ \\
\hline Psychological & -0.48 & 0.85 & -0.07 & 1.03 & -0.12 & 0.78 & 0.20 & 0.63 & 0.96 & 0.64 & 1.12 & 0.53 & $314.23 * * *$ & $2=3$, others differ \\
\hline
\end{tabular}

Health Behaviour in School-aged Children (HBSC) study, Finland, 2014

$* * * p<0.001$

${ }^{1} p<0.05$

group to which all other clusters were compared. Table 5 reports the odds ratios, the $95 \%$ CIs, and the $p$ values. The multi-level analysis indicated that there were significant differences between schools. The inter-school variance (variance partition coefficient, VPC) ranged from 1.9 to $12.4 \%$ of the total variance, depending on the indicator under scrutiny, and its effect was therefore controlled in the analyses.

The findings suggested that the adolescents in the 'Limited in most assets, despite medium affluence' cluster reported less physical activity, poorer self-rated health, and more symptoms than all the other clusters. For example, in the 'Rich in all assets' cluster, there was only one-third of the risk of being in the risk group for physical activity (0-2 days a week), as compared to the reference group. In oral health, healthy food, and smoking, all the clusters (with one exception, namely the 'Mostly average assets, though high affluence' cluster) indicated a lower likelihood of risk behaviour, or of having frequent and many symptoms, or of reporting fair or poor health, compared to the reference group. In fact, the 'Mostly average assets, though high affluence' cluster differed least from the reference group in all health behaviours and health indicators (Table 5). The cluster differences at the desirable end of the scales were here similar to those at the risk end.

\section{Discussion}

Among the adolescents under study, six profiles were identified, labelled as 'Limited in most assets despite medium affluence', 'Mostly average assets, but low affluence',
'Mostly average assets though high affluence', 'Mostly above average assets', 'Rich in most assets', and 'Rich in all assets'. There were statistically significant differences between the health asset profiles in terms of their associated health indicators (both regarding the risk level and the desirable level). The largest profile encompassed those moderately affluent adolescents who had below average levels of Family-social, School-social, Friends-social, Psychological, and Human assets (thus being 'Limited in most assets despite medium affluence'). The pupils in this asset profile reported the lowest frequency of physical activity and the lowest self-rated health (fair/poor). They also reported the highest frequency of having multiple health complaints more than once a week. On the other hand, those adolescents who were rich in most/all assets were systematically the least likely to belong to a risk group, in terms of all measured health indicators. This is in line with a previously reported finding, that the more the assets, the smaller the risk of belonging to the group of adolescents with unfavourable health indicators (Murphey et al. 2004).

According to our findings, having numerous assets was also associated with a greater likelihood of belonging to a group of adolescents with several favourable health indicators. Compared to the 'Limited in most assets, despite medium affluence' group, the adolescents in the 'Rich in most assets' or 'Rich in all assets' categories were systematically more likely to belong to a group with all desirable health indicators. Hence, having several health assets appears to protect from negative health indicators and also to promote good health.

However, though having more assets appeared to be better in most cases, there were only three out of eight 
Table 4 Proportions of adolescents (per given cluster) falling within the risk and desirable health categories for each health indicator

\begin{tabular}{|c|c|c|c|c|c|c|c|}
\hline & $\begin{array}{l}\text { Limited in most } \\
\text { assets, despite } \\
\text { medium } \\
\text { affluence }\end{array}$ & $\begin{array}{l}\text { Mostly average } \\
\text { assets, but low } \\
\text { affluence }\end{array}$ & $\begin{array}{l}\text { Mostly average } \\
\text { assets, though } \\
\text { high affluence }\end{array}$ & $\begin{array}{l}\text { Mostly above } \\
\text { average assets }\end{array}$ & $\begin{array}{l}\text { Rich in most } \\
\text { assets }\end{array}$ & $\begin{array}{l}\text { Rich in } \\
\text { all assets }\end{array}$ & Total \\
\hline \multicolumn{8}{|l|}{ Oral health } \\
\hline $\begin{array}{l}\text { Brushing teeth }<2 \\
\text { times a day (risk) }\end{array}$ & $\begin{array}{l}49.86 \% \\
(n=524)\end{array}$ & $\begin{array}{l}47.61 \% \\
(n=229)\end{array}$ & $\begin{array}{l}35.47 \% \\
(n=277)\end{array}$ & $\begin{array}{l}37.54 \% \\
(n=250)\end{array}$ & $\begin{array}{l}29.12 \% \\
(n=122)\end{array}$ & $\begin{array}{l}25.20 \% \\
(n=63)\end{array}$ & $\begin{array}{l}40.68 \% \\
(n=1465)\end{array}$ \\
\hline $\begin{array}{l}\text { Brushing teeth }>1 \text { time } \\
\text { per day (desirable) }\end{array}$ & $\begin{array}{l}50.14 \% \\
(n=527)\end{array}$ & $\begin{array}{l}52.39 \% \\
(n=252)\end{array}$ & $\begin{array}{l}64.53 \% \\
(n=504)\end{array}$ & $\begin{array}{l}62.46 \% \\
(n=416)\end{array}$ & $\begin{array}{l}70.88 \% \\
(n=297)\end{array}$ & $\begin{array}{l}74.80 \% \\
(n=187)\end{array}$ & $\begin{array}{l}59.84 \% \\
(n=2183)\end{array}$ \\
\hline \multicolumn{8}{|l|}{ Healthy food } \\
\hline 0-4 times/week (risk) & $\begin{array}{l}6.6 \% \\
(n=69)\end{array}$ & $\begin{array}{l}6.0 \% \\
(n=29)\end{array}$ & $\begin{array}{l}3.6 \% \\
(n=28)\end{array}$ & $\begin{array}{l}3.2 \% \\
(n=21)\end{array}$ & $\begin{array}{l}2.1 \% \\
(n=9)\end{array}$ & $\begin{array}{l}0.8 \% \\
(n=2)\end{array}$ & $\begin{array}{l}4.3 \% \\
(n=158)\end{array}$ \\
\hline $\begin{array}{l}\geq 7 \text { times/week } \\
(\text { desirable })\end{array}$ & $\begin{array}{l}77.19 \% \\
(n=812)\end{array}$ & $\begin{array}{l}79.50 \% \\
(n=384)\end{array}$ & $\begin{array}{l}85.79 \% \\
(n=670)\end{array}$ & $\begin{array}{l}87.24 \% \\
(n=581)\end{array}$ & $\begin{array}{l}91.17 \% \\
(n=382)\end{array}$ & $\begin{array}{l}94.40 \% \\
(n=236)\end{array}$ & $\begin{array}{l}84.95 \% \\
(3065)\end{array}$ \\
\hline \multicolumn{8}{|l|}{$\begin{array}{l}\text { Alcohol use (being } \\
\text { drunk) }\end{array}$} \\
\hline$\geq 2$ times (risk) & $\begin{array}{l}21.8 \% \\
(n=225)\end{array}$ & $\begin{array}{l}13.4 \% \\
(n=64)\end{array}$ & $\begin{array}{l}21.6 \% \\
(n=166)\end{array}$ & $\begin{array}{l}18.1 \% \\
(n=120)\end{array}$ & $\begin{array}{l}9.5 \% \\
(n=40)\end{array}$ & $\begin{array}{l}12.0 \% \\
(n=30)\end{array}$ & $\begin{array}{l}17.9 \% \\
(n=645)\end{array}$ \\
\hline Never (desirable) & $\begin{array}{l}68.57 \% \\
(n=707)\end{array}$ & $\begin{array}{l}78.71 \% \\
(n=377)\end{array}$ & $\begin{array}{l}69.22 \% \\
(n=533)\end{array}$ & $\begin{array}{l}74.55 \% \\
(n=495)\end{array}$ & $\begin{array}{l}84.01 \% \\
(n=352)\end{array}$ & $\begin{array}{l}81.60 \% \\
(n=204)\end{array}$ & $\begin{array}{l}73.84 \% \\
(n=2668)\end{array}$ \\
\hline \multicolumn{8}{|l|}{ Physical activity } \\
\hline 0-2 days/week (risk) & $\begin{array}{l}23.2 \% \\
(n=243)\end{array}$ & $\begin{array}{l}17.0 \% \\
(n=82)\end{array}$ & $\begin{array}{l}13.3 \% \\
(n=103)\end{array}$ & $\begin{array}{l}15.7 \% \\
(n=104)\end{array}$ & $\begin{array}{l}8.1 \% \\
(n=34)\end{array}$ & $\begin{array}{l}8.4 \% \\
(n=21)\end{array}$ & $\begin{array}{l}16.1 \% \\
(n=587)\end{array}$ \\
\hline 7 days/week (desirable) & $\begin{array}{l}17.4 \% \\
(182)\end{array}$ & $\begin{array}{l}19.13 \% \\
(n=92)\end{array}$ & $\begin{array}{l}21.42 \% \\
(n=166)\end{array}$ & $\begin{array}{l}21.08 \% \\
(n=140)\end{array}$ & $\begin{array}{l}26.25 \% \\
(n=110)\end{array}$ & $\begin{array}{l}34 \% \\
(n=85)\end{array}$ & $\begin{array}{l}21.32 \% \\
(n=775)\end{array}$ \\
\hline \multicolumn{8}{|l|}{ Smoking } \\
\hline $\begin{array}{l}\text { Weekly/more often } \\
\quad(\text { risk) }\end{array}$ & $\begin{array}{l}12.4 \% \\
(n=130)\end{array}$ & $\begin{array}{l}11.2 \% \\
(n=411)\end{array}$ & $\begin{array}{l}7.9 \% \\
(n=61)\end{array}$ & $\begin{array}{l}7.8 \% \\
(n=61)\end{array}$ & $\begin{array}{l}3.1 \% \\
(n=13)\end{array}$ & $\begin{array}{l}0.4 \% \\
(n=1)\end{array}$ & $\begin{array}{l}8.5 \% \\
(n=311)\end{array}$ \\
\hline $\begin{array}{l}\text { Do not smoke } \\
\text { (desirable) }\end{array}$ & $\begin{array}{l}80.69 \% \\
(n=848)\end{array}$ & $\begin{array}{l}85.27 \% \\
(n=411)\end{array}$ & $\begin{array}{l}86.19 \% \\
(n=668)\end{array}$ & $\begin{array}{l}87.54 \% \\
(n=583)\end{array}$ & $\begin{array}{l}94.50 \% \\
(n=418)\end{array}$ & $\begin{array}{l}95.60 \% \\
(n=239)\end{array}$ & $\begin{array}{l}86.33 \% \\
(n=3144)\end{array}$ \\
\hline \multicolumn{8}{|l|}{ Sleep length } \\
\hline$\leq 7 \mathrm{~h}($ risk $)$ & $\begin{array}{l}20.0 \% \\
(n=209)\end{array}$ & $\begin{array}{l}17.2 \% \\
(n=82)\end{array}$ & $\begin{array}{l}21.5 \% \\
(n=166)\end{array}$ & $\begin{array}{l}13.6 \% \\
(n=90)\end{array}$ & $\begin{array}{l}7.4 \% \\
(n=31)\end{array}$ & $\begin{array}{l}10.0 \% \\
(n=25)\end{array}$ & $\begin{array}{l}16.6 \% \\
(n=603)\end{array}$ \\
\hline$\geq 8.5 \mathrm{~h}($ desirable $)$ & $\begin{array}{l}41.51 \% \\
(n=433)\end{array}$ & $\begin{array}{l}48.95 \% \\
(n=233)\end{array}$ & $\begin{array}{l}38.60 \% \\
(n=298)\end{array}$ & $\begin{array}{l}49.40 \% \\
(n=328)\end{array}$ & $\begin{array}{l}63.48 \% \\
(n=266)\end{array}$ & $\begin{array}{l}54.22 \% \\
(n=135)\end{array}$ & $\begin{array}{l}46.73 \% \\
(n=1693)\end{array}$ \\
\hline \multicolumn{8}{|l|}{ Self-rated health } \\
\hline Fair/Poor (risk) & $\begin{array}{l}26.41 \% \\
(n=276)\end{array}$ & $\begin{array}{l}19.04 \% \\
(n=91)\end{array}$ & $\begin{array}{l}15.74 \% \\
(n=122)\end{array}$ & $\begin{array}{l}9.17 \% \\
(n=61)\end{array}$ & $\begin{array}{l}4.08 \% \\
(n=17)\end{array}$ & $\begin{array}{l}3.61 \% \\
(n=9)\end{array}$ & $\begin{array}{l}15.87 \% \\
(n=576)\end{array}$ \\
\hline $\begin{array}{l}\text { Good/Excellent } \\
\text { (desirable) }\end{array}$ & $\begin{array}{l}73.59 \% \\
(n=769)\end{array}$ & $\begin{array}{l}80.96 \% \\
(n=387)\end{array}$ & $\begin{array}{l}84.26 \% \\
(n=653)\end{array}$ & $\begin{array}{l}90.83 \% \\
(n=604)\end{array}$ & $\begin{array}{l}95.92 \% \\
(n=400)\end{array}$ & $\begin{array}{l}96.39 \% \\
(n=240)\end{array}$ & $\begin{array}{l}84.13 \% \\
(n=3053)\end{array}$ \\
\hline \multicolumn{8}{|l|}{$\begin{array}{l}\text { Subjective health } \\
\text { complaints }\end{array}$} \\
\hline $\begin{array}{l}>2 \text { symptoms more } \\
\text { than once a week } \\
(\text { risk) }\end{array}$ & $\begin{array}{l}39.3 \% \\
(n=412)\end{array}$ & $\begin{array}{l}34.7 \% \\
(n=167)\end{array}$ & $\begin{array}{l}34.3 \% \\
(n=267)\end{array}$ & $\begin{array}{l}21.1 \% \\
(n=140)\end{array}$ & $\begin{array}{l}11.0 \% \\
(n=46)\end{array}$ & $\begin{array}{l}18.0 \% \\
(n=45)\end{array}$ & $\begin{array}{l}29.6 \% \\
(n=1077)\end{array}$ \\
\hline $\begin{array}{c}\leq 2 \text { symptoms Once a } \\
\text { month or Seldom/ } \\
\text { Never (desirable) }\end{array}$ & $\begin{array}{l}28.4 \% \\
(n=298)\end{array}$ & $\begin{array}{l}36.4 \% \\
(n=175)\end{array}$ & $\begin{array}{l}28.5 \% \\
(n=222)\end{array}$ & $\begin{array}{l}40.5 \% \\
(n=269)\end{array}$ & $\begin{array}{l}59.7 \% \\
(n=222)\end{array}$ & $\begin{array}{l}52.0 \% \\
(n=130)\end{array}$ & $\begin{array}{l}38.9 \% \\
(n=1344)\end{array}$ \\
\hline
\end{tabular}

Health Behaviour in School-aged Children (HBSC) study, Finland, 2014 
Table 5 Risk behaviours and health indicators by cluster

\begin{tabular}{|c|c|c|c|c|c|c|c|c|c|}
\hline & & $\begin{array}{l}\text { Limited in most } \\
\text { assets, despite } \\
\text { medium } \\
\text { affluence }\end{array}$ & $\begin{array}{l}\text { Mostly average } \\
\text { assets, but low } \\
\text { affluence }\end{array}$ & $\begin{array}{l}\text { Mostly } \\
\text { average assets, } \\
\text { though high } \\
\text { affluence }\end{array}$ & $\begin{array}{l}\text { Mostly } \\
\text { above } \\
\text { average } \\
\text { assets }\end{array}$ & $\begin{array}{l}\text { Rich in } \\
\text { most } \\
\text { assets }\end{array}$ & $\begin{array}{l}\text { Rich in } \\
\text { all assets }\end{array}$ & $\begin{array}{l}\text { School } \\
\text { level } \\
\text { factor }\end{array}$ & \\
\hline \multicolumn{10}{|l|}{ Oral health } \\
\hline \multirow{3}{*}{$\begin{array}{r}\text { Brushing teeth }<2 \\
\text { times a day }(\text { risk })\end{array}$} & OR & 1.00 & 0.96 & 0.59 & 0.64 & 0.40 & 0.31 & Variance & 0.21 \\
\hline & $95 \% \mathrm{CI}$ & & $0.76-1.21$ & $0.48-0.73$ & $0.51-0.79$ & $0.30-0.52$ & $0.22-0.43$ & $95 \% \mathrm{CI}$ & $0.13-0.33$ \\
\hline & $p$ value & & 0.736 & $<0.001$ & $<0.001$ & $<0.001$ & $<0.001$ & & \\
\hline \multirow{3}{*}{$\begin{array}{l}\text { Brushing teeth }>1 \\
\text { time per day } \\
(\text { desirable })\end{array}$} & OR & 1.00 & 1.04 & 1.68 & 1.57 & 2.52 & 3.22 & Variance & 0.21 \\
\hline & $95 \% \mathrm{CI}$ & & $0.82-1.32$ & $1.37-2.07$ & $1.26-1.94$ & $1.94-3.28$ & $2.30-4.50$ & $95 \% \mathrm{CI}$ & $0.13-0.33$ \\
\hline & $p$ value & & 0.74 & $<0.001$ & $<0.001$ & $<0.001$ & $<0.001$ & & \\
\hline \multicolumn{10}{|l|}{ Healthy food } \\
\hline \multirow{3}{*}{$\begin{array}{l}\text { 0-4 times a week } \\
\quad \text { (risk) }\end{array}$} & OR & 1.00 & 0.96 & 0.58 & 0.50 & 0.33 & 0.11 & Variance & 0.06 \\
\hline & $95 \% \mathrm{CI}$ & & $0.61-1.52$ & $0.37-0.92$ & $0.30-0.83$ & $0.16-0.66$ & $0.03-0.47$ & $95 \% \mathrm{CI}$ & $0.00-5.75$ \\
\hline & $p$ value & & 0.874 & 0.020 & 0.007 & 0.002 & 0.003 & & \\
\hline \multirow{3}{*}{$\begin{array}{l}\geq 7 \text { times a week } \\
(\text { desirable })\end{array}$} & $\mathrm{OR}$ & 1.00 & 1.11 & 1.65 & 1.93 & 3.06 & 5.13 & Variance & 0.13 \\
\hline & $95 \% \mathrm{CI}$ & & $0.84-1.46$ & $1.27-2.13$ & $1.46-2.55$ & $2.10-4.46$ & $2.91-9.06$ & $95 \% \mathrm{CI}$ & $0.06-0.35$ \\
\hline & $p$ value & & 0.450 & $<0.001$ & $<0.001$ & $<0.001$ & $<0.001$ & & \\
\hline \multicolumn{10}{|l|}{ Alcohol use } \\
\hline Being drunk: & OR & 1.00 & 0.56 & 1.14 & 0.84 & 0.39 & 0.52 & Variance & 0.22 \\
\hline \multirow[t]{2}{*}{$\geq 2$ times (risk) } & $95 \% \mathrm{CI}$ & & $0.40-0.77$ & $0.89-1.47$ & $0.64-1.10$ & $0.26-0.56$ & $0.33-0.81$ & $95 \% \mathrm{CI}$ & $0.12-0.42$ \\
\hline & $p$ value & & $<0.001$ & 0.310 & 0.202 & $<0.001$ & 0.004 & & \\
\hline \multirow[t]{3}{*}{ Never (desirable) } & OR & 1.00 & 1.66 & 0.92 & 1.29 & 2.38 & 1.91 & Variance & 0.21 \\
\hline & $95 \% \mathrm{CI}$ & & $1.26-2.20$ & $0.73-1.15$ & $1.01-1.64$ & $1.74-3.27$ & $1.31-2.79$ & $95 \% \mathrm{CI}$ & $0.12-0.37$ \\
\hline & $p$ value & & $<0.001$ & 0.467 & 0.037 & $<0.001$ & 0.001 & & \\
\hline \multicolumn{10}{|l|}{ Physical activity } \\
\hline \multirow{3}{*}{$\begin{array}{l}0-2 \text { days a week } \\
\text { (risk) }\end{array}$} & OR & 1.00 & 0.68 & 0.50 & 0.60 & 0.29 & 0.31 & Variance & 0.12 \\
\hline & $95 \% \mathrm{CI}$ & & $0.51-0.90$ & $0.39-0.65$ & $0.46-0.78$ & $0.20-0.43$ & $0.19-0.50$ & $95 \% \mathrm{CI}$ & $0.05-0.32$ \\
\hline & $p$ value & & 0.007 & $<0.001$ & $<0.001$ & $<0.001$ & $<0.001$ & & \\
\hline \multirow{3}{*}{$\begin{array}{c}7 \text { days a week } \\
\text { (desirable) }\end{array}$} & OR & 1.00 & 1.11 & 1.30 & 1.29 & 1.68 & 2.37 & Variance & 0.10 \\
\hline & $95 \% \mathrm{CI}$ & & $0.84-1.48$ & $1.02-1.66$ & $1.00-1.65$ & $1.27-2.22$ & $1.73-3.26$ & $95 \% \mathrm{CI}$ & $0.04-$ \\
\hline & $p$ value & & 0.448 & 0.031 & 0.051 & $<0.001$ & $<0.001$ & & 0.26 \\
\hline \multicolumn{10}{|l|}{ Smoking } \\
\hline \multirow{3}{*}{$\begin{array}{c}\text { Weekly/More } \\
\text { often (risk) }\end{array}$} & OR & 1.00 & 0.93 & 0.68 & 0.62 & 0.24 & 0.03 & Variance & 0.45 \\
\hline & $95 \% \mathrm{CI}$ & & $0.65-1.34$ & $0.48-0.95$ & $0.43-0.88$ & $0.13-0.43$ & $0.00-0.23$ & $95 \% \mathrm{CI}$ & $0.25-0.82$ \\
\hline & $p$ value & & 0.702 & 0.026 & 0.008 & $<0.001$ & 0.001 & & \\
\hline \multirow{3}{*}{$\begin{array}{l}\text { Do not smoke } \\
(\text { desirable })\end{array}$} & OR & 1.00 & 1.33 & 1.36 & 1.62 & 4.15 & 4.51 & Variance & 0.47 \\
\hline & $95 \% \mathrm{CI}$ & & $0.97-1.83$ & $1.03-1.79$ & $1.21-2.18$ & $2.60-6.62$ & $2.37-8.59$ & $95 \% \mathrm{CI}$ & $0.29-0.74$ \\
\hline & $p$ value & & 0.074 & 0.029 & 0.001 & $<0.001$ & $<0.001$ & & \\
\hline \multicolumn{10}{|l|}{ Sleep length } \\
\hline \multirow[t]{3}{*}{$<7 \mathrm{~h}($ risk $)$} & OR & 1.00 & 0.84 & 1.11 & 0.63 & 0.32 & 0.45 & Variance & 0.11 \\
\hline & $95 \% \mathrm{CI}$ & & $0.63-1.12$ & $0.87-1.40$ & $0.48-0.83$ & $0.22-0.48$ & $0.29-0.71$ & $95 \% \mathrm{CI}$ & $0.04-0.33$ \\
\hline & $p$ value & & 0.232 & 0.398 & 0.001 & $<0.001$ & 0.001 & & \\
\hline \multirow[t]{3}{*}{$\geq 8.5 \mathrm{~h}($ desirable $)$} & OR & 1.00 & 1.35 & 0.87 & 1.39 & 2.46 & 1.68 & Variance & 0.15 \\
\hline & $95 \% \mathrm{CI}$ & & $1.07-1.70$ & $0.71-1.07$ & $1.13-1.71$ & $1.92-3.15$ & $1.25-2.26$ & $95 \% \mathrm{CI}$ & $0.09-0.27$ \\
\hline & $p$ value & & 0.011 & 0.187 & 0.002 & $<0.001$ & 0.001 & & \\
\hline \multicolumn{10}{|l|}{ Self-rated health } \\
\hline \multirow[t]{3}{*}{ Fair/poor (risk) } & OR & 1.00 & 0.65 & 0.52 & 0.28 & 0.12 & 0.10 & Variance & 0.14 \\
\hline & $95 \% \mathrm{CI}$ & & $0.50-0.86$ & $0.40-0.66$ & $0.21-0.38$ & $0.07-0.19$ & $0.05-0.21$ & $95 \% \mathrm{CI}$ & $0.06-0.34$ \\
\hline & $p$ value & & 0.002 & $<0.001$ & $<0.001$ & $<0.001$ & $<0.001$ & & \\
\hline
\end{tabular}


Table 5 (continued)

\begin{tabular}{|c|c|c|c|c|c|c|c|c|c|}
\hline & & $\begin{array}{l}\text { Limited in most } \\
\text { assets, despite } \\
\text { medium affluence }\end{array}$ & $\begin{array}{l}\text { Mostly average } \\
\text { assets, but low } \\
\text { affluence }\end{array}$ & $\begin{array}{l}\text { Mostly average } \\
\text { assets, though } \\
\text { high affluence }\end{array}$ & $\begin{array}{l}\text { Mostly } \\
\text { above } \\
\text { average } \\
\text { assets }\end{array}$ & $\begin{array}{l}\text { Rich in } \\
\text { most } \\
\text { assets }\end{array}$ & $\begin{array}{l}\text { Rich in all } \\
\text { assets }\end{array}$ & $\begin{array}{l}\text { School } \\
\text { level } \\
\text { factor }\end{array}$ & \\
\hline \multirow{3}{*}{$\begin{array}{l}\text { Good/excellent } \\
\text { (desirable) }\end{array}$} & OR & \multirow[t]{3}{*}{1.00} & 1.53 & 1.94 & 3.59 & 8.65 & 9.68 & Variance & 0.14 \\
\hline & $95 \% \mathrm{CI}$ & & $1.16-2.01$ & $1.52-2.47$ & $2.66-4.86$ & $5.20-14.40$ & $4.88-19.19$ & $95 \% \mathrm{CI}$ & $0.06-0.34$ \\
\hline & $p$ value & & 0.002 & $<0.001$ & $<0.001$ & $<0.001$ & $<0.001$ & & \\
\hline \multicolumn{10}{|l|}{$\begin{array}{l}\text { Subjective health } \\
\text { complaints }\end{array}$} \\
\hline \multirow{3}{*}{$\begin{array}{l}\geq 2 \text { symptoms } \\
\text { more than once a } \\
\text { week (risk) }\end{array}$} & OR & \multirow[t]{3}{*}{1.00} & 0.76 & 0.74 & 0.36 & 0.17 & 0.32 & Variance & 0.09 \\
\hline & $95 \% \mathrm{CI}$ & & $0.62-0.99$ & $0.60-0.91$ & $0.29-0.46$ & $0.12-0.24$ & $0.22-0.46$ & $95 \%$ CI & $0.04-0.23$ \\
\hline & $p$ value & & 0.044 & 0.003 & $<0.001$ & $<0.001$ & $<0.001$ & & \\
\hline \multirow{3}{*}{$\begin{array}{l}\leq 2 \text { symptoms } \\
\text { once a month or } \\
\text { Seldom/Never } \\
\text { (desirable) }\end{array}$} & $\mathrm{OR}$ & \multirow[t]{3}{*}{1.00} & 1.51 & 1.08 & 1.87 & 4.17 & 2.90 & Variance & 0.08 \\
\hline & $95 \% \mathrm{CI}$ & & $1.19-1.92$ & $0.87-1.33$ & $1.51-2.31$ & $3.25-5.34$ & $2.16-3.90$ & $95 \% \mathrm{CI}$ & $0.04-0.20$ \\
\hline & $p$ value & & 0.001 & 0.492 & $<0.001$ & $<0.001$ & $<0.001$ & & \\
\hline
\end{tabular}

Mixed effect binary logistic regression models per cluster: odds ratios (OR), 95\% confidence intervals (CI), and variance of the school level factor. *The first cluster (Limited in most assets, despite medium affluence) is the reference category. Health Behaviour in School-aged Children (HBSC) study, Finland, 2014

*Adjusted for gender and age group. Reference group marked as 1.00 throughout

health indicators (physical activity, self-rated health, and multiple health complaints) for which the risk was significantly higher in the reference profile ('Limited in most assets despite medium affluence') than in the other profiles. Moreover, in relation to favourable health indicators, the reference group did not systematically report desirable health outcomes less often for all the indicators. This may indicate that certain groups of assets do indeed predict certain health outcomes (Benson et al. 2011). It may also be that some individual assets may be more crucial than other assets in protecting from certain kinds of risky behaviour or poorer health, and in promoting certain favourable health outcomes. An interesting finding was that high family affluence alone did not protect adolescents from health-harming behaviours, or from low self-reported health. Neither did low family affluence alone automatically expose a child to unfavourable health outcomes. The findings allow us to suggest that even although socioeconomic inequalities in child health are a major problem, and although in many countries the gap between socioeconomic groups has deepened with regard to adolescent health (Elgar et al. 2015), efforts to promote other health protective factors - which are often immaterial-may tend to even out such a financially rooted gap. Indeed, the role of immaterial resources has been highlighted previously in health disparity discussions. Thus, Mackenbach (2012, p. 766) has noted that the policies of welfare states have "contributed to making an "affluent lifestyle" widely affordable'; nevertheless, they may paradoxically 'have contributed to a widening of health inequalities' by overlooking the importance of immaterial resources.
The findings underline the importance of identifying those children who lack various health-protecting and health-promoting factors, and who are thus more vulnerable to poorer health outcomes. A longitudinal study by Frech (2012; see also Cheney et al. 2015) indicated that the resources possessed by adolescents, such as social support from family, school, and friends, plus various psychosocial factors, had 'a persistent role in promoting healthy behaviour engagement during the transition to adulthood' ( $\mathrm{p}$. 67). Although the present study produced important information on various asset profiles and on their associations with several health indicators, it did not focus on individuals' genuine possibilities and abilities to make health-promoting choices going beyond the health assets they possess. As discussed by Abel and Frohlich (2012) in the field of capital research, possession of health resources may not in itself decrease disparities; inequalities also exist in options to make healthy choices, and in people's abilities to actively use various sets of health resources in ways that promote health.

Due to the nature of the constructs measured, conclusions cannot be drawn regarding the effects of unique factors (e.g. loneliness) or of broader assets (e.g. Friendssocial) on specific health indicators. Furthermore, additional research is needed on those health indicators that could not be explained by the number of health assets possessed, with efforts to identify the interplay between the unique factors that may both increase and decrease health inequalities-bearing in mind that one individual's asset may not necessarily be everyone's asset (cf. De Clercq et al. 2016). Indeed, more discussion is needed on the 
complexity of interplay between the resources and health behaviour plus health, as has been done in the capital field (e.g. Kawachi and Berkman 2014). Moreover, health assets approach in general has been criticized that while the focus has been on the determinants of health rather than illness and on what people have rather than lack, several complex issues have been avoided such as the discussion about the social gradient of health as well as how health has been shaped by those with power and wealth (Friedli 2013). Critical examination of these could develop the field further. There is also a need for more research employing objective health measures instead of purely subjective ones. Self-reported data are always susceptible to the tendency to provide socially desirable responses, and this can apply also to reports on health behaviours.

To conclude, adolescents differ in their asset profiles. Having multiple health assets appears to protect adolescents from risky behaviour and poor health, and to promote the acquisition of favourable health outcomes. This being so, the development of health assets may contribute to reducing differences in health (Morgan and Ziglio 2007). Furthermore, although the development of even a single asset may bring about positive changes (Murphey et al. 2004), adolescents could benefit more from health promotion and public health initiatives that would support them in acquiring a broad range of assets capable of protecting and promoting health.

Acknowledgements Open access funding provided by University of Jyväskylä (JYU).

Funding The research was funded by Ministry of Social affairs and Health, Juho Vainio Foundation, and Academy of Finland (\#276239, \#284439, and \#313768).

\section{Compliance with ethical standards}

Ethical approval The survey was carried out voluntarily, through passive or active consent, depending on the procedures of individual municipalities. Respondents had the right to withdraw. No personal identifiers were used, and the data were anonymous. The Finnish HBSC study was approved by the Finnish Teachers' Trade Union and by the Finnish National Agency for Education when the survey was conducted initially. Approval has not subsequently been sought for each survey year, since the procedure has been the same in each year, and no objections have been brought to our attention.

Open Access This article is distributed under the terms of the Creative Commons Attribution 4.0 International License (http://creative commons.org/licenses/by/4.0/), which permits unrestricted use, distribution, and reproduction in any medium, provided you give appropriate credit to the original author(s) and the source, provide a link to the Creative Commons license, and indicate if changes were made.

\section{References}

Abel T (2008) Cultural capital and social inequality in health. J Epidemiol Community Health 62(7):e13

Abel T, Frohlich KL (2012) Capitals and capabilities: linking structure and agency to reduce health inequalities. Soc Sci Med 74(2):236-244

Benson PL, Scales PC, Leffert N, Roehlkepartain EC (1999) A fragile foundation: the state of developmental assets among American youth. Search Institute, Minneapolis

Benson PL, Scales PC, Syvertsen AK (2011) The contribution of the developmental assets framework to positive youth development theory and practice. Adv Child Dev Behav 41:197-230

Brooks F, Kendall S (2013) Making sense of assets: what can an assets based approach offer public health? Crit Public Health 23(2):127-130

Brooks FM, Magnusson J, Spencer N, Morgan A (2012) Adolescent multiple risk behaviour: an asset approach to the role of family, school and community. J Public Health 34(suppl_1):i48-i56

Brown BB, Mounts N, Lamborn SD, Steinberg L (1993) Parenting practices and peer group affiliation in adolescence. Child Dev 64(2):467-482

Cheney MK, Oman RF, Vesely SK (2015) Prospective associations among youth assets in young adults and tobacco use. Am J Prev Med 48(1):S94-S101

Chu PS, Saucier DA, Hafner E (2010) Meta-analysis of the relationships between social support and well-being in children and adolescents. J Soc Clin Psychol 29(6):624-645

De Clercq B, Abel T, Moor I, Elgar FJ, Lievens J, Sioen I, Braeckman L, Deforche B (2016) Social inequality in adolescents' healthy food intake: the interplay between economic, social and cultural capital. Eur J Public Health 27(2):279-286

Elgar FJ, Pförtner TK, Moor I, De Clercq B, Stevens GW, Currie C (2015) Socioeconomic inequalities in adolescent health 2002-2010: a time-series analysis of 34 countries participating in the Health Behaviour in School-aged Children study. Lancet 385(9982):2088-2095

Forde I, Raine R (2008) Placing the individual within a social determinants approach to health inequity. Lancet 372(9650):1694-1696

Frech A (2012) Healthy behavior trajectories between adolescence and young adulthood. Adv Life Course Res 17(2):59-68

Friedli L (2013) 'What we've tried, hasn't worked': the politics of assets based public health. Critic Public Health 23(2):131-145

Fulkerson JA, Story M, Mellin A, Leffert N, Neumark-Sztainer D, French SA (2006) Family dinner meal frequency and adolescent development: relationships with developmental assets and highrisk behaviors. J Adolesc Health 39(3):337-345

García-Moya I, Brooks F, Morgan A, Moreno C (2015) Subjective well-being in adolescence and teacher connectedness: a health asset analysis. Health Educ J 74(6):641-654

Gilbert KL, Quinn SC, Goodman RM, Butler J, Wallace J (2013) A meta-analysis of social capital and health: a case for needed research. J Health Psychol 18(11):1385-1399

Haugland S, Wold B, Stevenson J, Aaro L, Woynarowska B (2001) Subjective health complaints in adolescence. A cross national comparison of the prevalence and dimensionality. Eur J Public Health 11(1):4-10

IBM (2012) Cluster evaluation algorithms. In IBM SPSS modeler 15 algorithms guide. IBM Corporation, New York

Inchley J, Currie D, Young T, Samdal O, Torsheim T, Augustson L, Mathison F, Aleman-Diaz A, Molcho M, Weber M, Barnekow V (2016) Growing up unequal: gender and socioeconomic differences in young people's health and well-being. Health Behavior in School-Aged Children (HBSC) study, International report 
from the 2013/2014 survey. Health Policy for Children and Adolescents, No. 7. Copenhagen, World Health Organization

Kawachi I, Berkman L (2014) Social cohesion, social capital, and health. In: Berkman LF, Kawachi I, Glymour MM (eds) Social epidemiology, 2nd edn. Oxford University Press, Oxford, pp 290-319

Ketchen DJ Jr, Shook CL (1996) The application of cluster analysis in strategic management research: an analysis and critique. Strateg Manag J 17(6):441-458

Klemera E, Brooks FM, Chester KL, Magnusson J, Spencer N (2017) Self-harm in adolescence: protective health assets in the family, school and community. Int J Public Health 62(6):631-638

Leffert N, Benson PL, Scales PC, Sharma AR, Drake DR, Blyth DA (1998) Developmental assets: measurement and prediction of risk behaviors among adolescents. Appl Dev Sci 2(4):209-230

Mackenbach JP (2012) The persistence of health inequalities in modern welfare states: the explanation of a paradox. Soc Sci Med 75(4):761-769

Marmot M (2005) Social determinants of health inequalities. Lancet 365(9464):1099-1104

Morgan A, Ziglio E (2007) Revitalising the evidence base for public health: an assets model. Promot Educ 14(2_suppl):17-22

Murphey DA, Lamonda KH, Carney JK, Duncan P (2004) Relationships of a brief measure of youth assets to health-promoting and risk behaviors. J Adolesc Health 34(3):184-191

Orbach I, Mikulincer M (1998) The body investment scale: construction and validation of a body experience scale. Psychol Assess 10(4):415-425

Paakkari O, Torppa M, Kannas L, Paakkari L (2016) Subjective health literacy: development of a brief instrument for schoolaged children. Scand J Public Health 44(8):751-757

Prochaska JJ, Sallis JF, Long B (2001) A physical activity screening measure for use with adolescents in primary care. Arch Pediatr Adolesc Med 155(5):554-559
Ravens-Sieberer U, Erhart M, Torsheim T, Hetland J, Freeman J, Danielson M, Thomas C, HBSC Positive Health Group (2008) An international scoring system for self-reported health complaints in adolescents. Eur J Public Health 18(3):294-299

Reiss F (2013) Socioeconomic inequalities and mental health problems in children and adolescents: a systematic review. Soc Sci Med 90:24-31

Rosenberg M (1965) Society and the adolescent self-image. Princeton University Press, Princeton

Shim JK (2010) Cultural health capital: a theoretical approach to understanding health care interactions and the dynamics of unequal treatment. J Health Soc Behav 51(1):1-5

Torsheim T, Cavallo F, Levin KA, Schnohr C, Mazur J, Niclasen B, Currie C, FAS Development Study Group (2016) Psychometric validation of the revised family affluence scale: a latent variable approach. Child Indic Res 9(3):771-784

Viner RM, Ozer EM, Denny S, Marmot M, Resnick M, Fatusi A, Currie C (2012) Adolescence and the social determinants of health. Lancet 379(9826):1641-1652

World Health Organization (2008) Closing the gap in a generation: Health equity through action of the social determinants of health. Commission of the Social Determinants of Health. World Health Organization, Geneva

Zimet GD, Dahlem NW, Zimet SG, Farley GK (1988) The multidimensional scale of perceived social support. J Personal Assess 52:30-41

Publisher's Note Springer Nature remains neutral with regard to jurisdictional claims in published maps and institutional affiliations. 